\title{
Regulacyjne środowisko testowe (regulatory sandbox) - doświadczenia i perspektywy
}

Regulatory sandbox for financial innovations: experiences and perspectives: The article looks at regulatory sandbox, i.e. a new technology which seeks to provide companies with the ability to test products and services in a controlled environment and aims at increasing regulatory standards in financial services. The article begins with explaining the rationale behind the development of regulatory technology. Next, the author provides an analysis of regulatory sandbox. She discusses international experiences with particular attention given to the British model, presents possible outline of Polish regulatory sandbox, and looks at the prospects for establishing European framework.

Słowa kluczowe: regulacyjne środowisko testowe, piaskownica regulacyjna, innowacje finansowe, fintech

Keywords: regulatory testing environment, regulatory sandbox, financial innovations, FinTech

* Doktor hab. nauk ekonomicznych, profesor Uniwersytetu Ekonomicznego w Poznaniu, specjalista ds. finansów publicznych w BAS; e-mail: kamilla.marchewka-bartkowiak@sejm.gov.pl.

\section{Wstęp}

Regulacyjne środowiska testowe (ang. regulatory sandboxes, RS), które potocznie w języku polskim zwane mogą być piaskownicami lub wylęgarniami, tworzą obecnie jedno $\mathrm{z}$ innowacyjnych narzędzi oceny skutków regulacji o charakterze ex-ante (regulatory impact assessment ex-ante, RIA). Tego rodzaju środowiska testowe wykorzystywane są także w innych dziedzinach, jak chociażby w medycynie do testowania eksperymentalnych leków. W analizowanym w tym artykule przypadku eksperyment dotyczy jednak innowacyjnych produktów i usług finansowych lub modeli biznesowych tworzonych na bazie nowych technologii, szczególnie w rozwijającym się bardzo dynamicznie sektorze fintech. Regula- 
cyjne środowisko testowe można zatem określić jako środowisko specjalnie stworzone przez regulatora publicznego w celu przetestowania w odizolowanym otoczeniu (np. grupie klientów) możliwych skutków wdrożenia nowego rozwiązania technologicznego. Głównym celem zatem zorganizowania tego „eksperymentu” jest weryfikacja założeń nowatorskiego rozwiązania, ale także ocena przez regulatora, czy dana koncepcja wpisuje się w obowiązujący zakres regulacji lub czy wymaga innych rozwiązań, aby mogła zostać wdrożona na szeroką skalę. Wypełnienie określonych przez regulatora zasad testowania może też wiązać się z otrzymaniem określonego typu licencji na dany obszar obowiązywania odpowiednich regulacji (np. państwo czy region).

Regulacyjne środowiska testowe stosowane są już obecnie w ok. 20 państwach na świecie, w tym m.in. w Europie - w Wielkiej Brytanii ${ }^{1}$, Holandii ${ }^{2}$, Danii $^{3}$, Szwajcarii ${ }^{4}$, ponadto w Australii ${ }^{5}$, Kanadzie ${ }^{6}$ oraz w Hongkongu ${ }^{7}$, Singapurze $^{8}$, Indonezji, ${ }^{9}$ Malezji $^{10}$, Tajwanie ${ }^{11}, \mathrm{Abu} \mathrm{Dhabi}^{12}$, a także w Arizonie, jako pierwszym stanie USA ${ }^{13}$.

W Unii Europejskiej również pojawiają się analizy i propozycje dotyczące ujednolicenia procesu tworzenia przez państwa członkowskie regulacyjnych środowisk testowych. W przyjętym przez Komisję Europejską „Planie działań w zakresie technologii finansowych" ${ }^{14}$ deklarowane jest stworzenie na początku 2019 r. we współpracy z europejskimi urzędami nadzoru najlepszych praktyk w tym zakresie. Ponadto pojawiają się już postulaty utworzenia europejskiej piaskownicy regulacyjnej jako „bezpiecznej przestrzeni” (safe space) testowania regulacji na poziomie unijnym.

${ }^{1}$ Https://www.fca.org.uk/firms/regulatory-sandbox.

2 Https://www.dnb.nl/en/supervision/innovationhub/maatwerk-voor-innovatie-regulatorysandbox/index.jsp.

${ }^{3}$ Https://www.finanstilsynet.dk/en/Tilsyn/Information-om-udvalgtetilsynsomraader/ Fintech/FT-Lab.

${ }^{4}$ Https://www.finma.ch/en/news/2016/03/20160317-mm-fintech.

${ }^{5} \mathrm{Http}$ ///asic.gov.au/for-business/your-business/innovation-hub/regulatory-sandbox.

${ }^{6} \mathrm{Https} / / /$ www.securities-administrators.ca/industry_resources.aspx? $\mathrm{id}=1588$.

7 Http://www.hkma.gov.hk/eng/key-functions/international-financial-centre/fintech-supervisorysandbox.shtml.

${ }^{8} \mathrm{Http}: / /$ www.mas.gov.sg/Singapore-Financial-Centre/Smart-Financial-Centre/FinTech-Regulatory-Sandbox.aspx $>$.

9 Http://www.bi.go.id/en/ruang-media/siaran-pers/Pages/sp_187316.asp.x.

10 Http://www.bnm.gov.my/index.php?ch=en_announcement\&pg=en_ announcement\&ac $=467$.

11 Https://www.fsc.gov.tw.

$12 \mathrm{Http} / / /$ fintech.adgm.com/regulatory-laboratory.

13 Https://www.azag.gov/press-release/arizona-becomesfirst-state-us-offer-fintech-regulatory-sandbox.

${ }^{14} \operatorname{COM}(2018) 109$ final. 
Celem artykułu jest analiza dotychczasowych doświadczeń w tworzeniu i funkcjonowaniu regulacyjnych środowisk testowych, ze szczególnym uwzględnieniem państw UE, w tym także polskiej piaskownicy regulacyjnej. Autorka przedstawi też rozważania na temat możliwości powołania przedmiotowego rozwiązania jako jednolitego dla całej Unii.

\section{Regulatory sandboxes - doświadczenia międzynarodowe}

Rozważając problematykę regulacyjnych środowisk testowych, należy przede wszystkim rozpocząć od pytania, dlaczego proces ich tworzenia rozpoczął się właśnie teraz, skoro innowacje finansowe powstawały już wcześniej i powiązane były z równie szybko rozwijającą się bankowością elektroniczną. Odpowiedź wiąże się przede wszystkim $\mathrm{z}$ zakresem i tempem wdrażania nowych technologii informatycznych do tworzenia pozabankowych produktów finansowych w ramach nowych organizacji biznesowych (start-up). Jak wskazuje Europejski Urząd Nadzoru Bankowego (European Banking Authority, EBA) ${ }^{15}$, sektor fintech jest obecnie najbardziej innowacyjnym i konkurencyjnym sektorem na świecie.

Ogólnie można stwierdzić, że wiele sektorów gospodarki (w tym sektor finansowy) musi współcześnie mierzyć się z szybko wzrastającym zapotrzebowaniem klientów na coraz efektywniejsze, lepsze jakościowo i tańsze produkty i usługi. Innowacje są zatem obarczone takimi cechami, jak „krótki czas życia”, łatwość w kopiowaniu, personalizacja, czyli oczekiwana indywidualizacja podejścia do klienta, który z jednej strony wymaga coraz to ciekawszych dla niego nowinek technologicznych, ale z drugiej strony oczekuje prawnej ochrony dostępu do informacji o nim samym.

Należy mieć zatem świadomość, że finansowe innowacje technologiczne to tylko początek tworzenia produktów i usług, które na bazie nowych technologii, jak m.in. sztuczna inteligencja (artificial inteligence, AI), technologia rozproszonego rejestru (distributed ledger technology, DLT), łańcuch bloków (blockchain) czy przechowywanie, analiza i przetwarzanie dużych zbiorów danych (Cloud Computing i Big Data), będą wdrażane w całej gospodarce i będą wymagały szybkich oraz skutecznych dostosowań regulacyjnych.

Współcześnie tworzone piaskownice regulacyjne nakierowane są głównie na wspomaganie rozwoju sektora fintech. Jednak na regulacyjne środowiska testowe już teraz należałoby spojrzeć szerzej, uwzględniając ich cel i zakres działalności oraz organizację. Generalnie bowiem piaskownice regulacyjne to dość prosta koncepcja stworzenia wydzielonego, bezpiecznego środowiska, w którym można eksperymentować bez ponoszenia prawnych konsekwencji porażki, przydatna wszędzie tam, gdzie nowe przedsięwzięcia napotykają wysokie barie-

${ }_{15}$ Regulatory sandboxes. A proposal to EBA by the Banking Stakeholders Group, EBA, July 2017. 
ry wejścia związane głównie z koniecznością posiadania licencji ${ }^{16}$ (określonego rodzaju zezwolenia na prowadzenie działalności).

Jak wspomniano we wstępie, środowiska testowe w zakresie krajowych regulacji stają się coraz popularniejszym narzędziem regulatorów i nadzorców publicznych na świecie. Sandbox jest już jednak bardziej zaawansowaną formułą bezpośredniego kontaktu tych podmiotów z interesariuszami. Do innych rozwiązań możemy zaliczyć tworzone przez instytucje publiczne różnego rodzaju fora konsultacyjne oraz centra innowacji ${ }^{17}$ (innovation hubs). Dwa ostatnie rozwiązania mają jednak głównie charakter platform komunikacyjnych, w których regulatorzy/nadzorcy wykorzystują odpowiednie, indywidualne wytyczne czy wskazówki. Z danych ankietowych uzyskanych przez EBA ${ }^{18}$ w 2017 r. wynika, że zasady tworzone w zorganizowanych środowiskach testowych były znane ok. $8 \%$ respondentom reprezentującym nadzorców głównie z państw UE. Ponadto $46 \%$ zadeklarowało wprowadzenie innych rozwiązań regulacyjnych (w tym centrów innowacji), a pozostałe $46 \%$ nie widziało potrzeby zastosowania omawianych reżimów regulacyjnych. Powyższe wyniki unaoczniają z jednej strony innowacyjny charakter piaskownic regulacyjnych, ale z drugiej strony wskazują na konieczność analizy korzyści i kosztów ich powoływania.

Pierwsze regulacyjne środowisko testowe zostało stworzone przez brytyjski Urząd Nadzoru Finansowego (Financial Conduct Authority, FCA) w 2015 r. pod nazwą Project Innovate. Program wdrażany był już w kilku etapach (tzw. kohortach), gdzie firmy z sektora fintech ubiegać się mogą o udział na każdym etapie (tabela 1). Głównym celem sandboxa jest ${ }^{19}$ :

- możliwość testowania produktów i usług w kontrolowanym środowisku,

- skrócenie czasu wprowadzenia produktu na rynek przy potencjalnie niższych kosztach,

- wsparcie w określaniu odpowiednich zabezpieczeń w zakresie ochrony konsumentów w celu tworzenia nowych produktów i usług,

- umożliwienie polepszenia dostępu do finansowania innowacji.

Financial Conduct Authority określa zatem odgórnie kryteria, które musi spełnić innowacja (definiowana jako produkt, usługa, model biznesowy oraz mechanizm dostarczania), aby została zaakceptowana do testowania. Do kryteriów tych zalicza się:

16 W. Szpringer, Nowe technologie a sektor finansowy. Fintech jako szansa i zagrożenie, Poltext, Warszawa 2018, s. 88.

17 Więcej na ten temat zob. K. Marchewka-Bartkowiak, Wyzwania regulacyjne związane z innowacjami technologicznymi i produktowymi [w:] Banki w nowym otoczeniu społecznym, gospodarczym i technologicznym, red. E. Miklaszewska, Poltext, Warszawa 2018.

${ }_{18}$ Discussion Paper on the EBA's approach to financial technology (FinTech), EBA, August 2017.

19 Regulatory sandbox, FCA, November 2015. 
- zakres wdrożenia (przewidywany zasięg do rynku brytyjskiego lub poza $\operatorname{nim})$,

- innowacyjność (wskazanie innowacji jako pierwotnej lub też wtórnej modyfikacji rozwiązań już istniejących),

- korzyści dla klienta (w tym także określenie ryzyka i potencjalnie negatywnego wpływu),

- potrzeba testowania (w tym występujące niedopasowanie regulacyjne innowacji, zbyt kosztowne warunki testowania poza FCA),

- gotowość do testowania na rzeczywistym rynku (w tym plan testowania, zasoby do jego przeprowadzenia, wystarczające zabezpieczenie ochrony klientów oraz możliwości zadośćuczynienia w razie niepowodzenia testu).

Tabela 1. Regulatory sandbox w Wielkiej Brytanii (etapy testowania)

\begin{tabular}{|c|c|c|c|}
\hline $\begin{array}{l}\text { Numer etapu } \\
\text { (kohorty) }\end{array}$ & $\begin{array}{c}\text { Liczba zgłoszonych } \\
\text { wniosków }\end{array}$ & $\begin{array}{c}\text { Zaakceptowane } \\
\text { wnioski }\end{array}$ & Przykłady innowacji \\
\hline $\begin{array}{l}\text { l etap } \\
\text { lipiec } 2016\end{array}$ & 69 & $\begin{array}{c}24 \\
18 \text { przetestowa- } \\
\text { nych innowacji }\end{array}$ & $\begin{array}{l}\text { Billon (platforma e-money bazująca na DLT) } \\
\text { BitX (przelewy transgraniczne obsługiwane przez } \\
\text { waluty cyfrowe i technologię blockchain) } \\
\text { Citizens Advice (narzędzie doradcze w zakresie } \\
\text { zadłużenia) } \\
\text { SETL (smart-card) } \\
\text { Swave (aplikacja i usługa internetowa tworząca } \\
\text { tożsamość osobistą lub handlową) }\end{array}$ \\
\hline $\begin{array}{l}\text { Il etap } \\
\text { styczeń } 2017\end{array}$ & 77 & $\begin{array}{c}31 \\
24 \text { przetestowa- } \\
\text { ne innowacje }\end{array}$ & $\begin{array}{l}\text { Disberse (dostawca usług opartych na blockchainie, } \\
\text { który dystrybuuje i śledzi rozwój i finansowanie } \\
\text { humanitarne) } \\
\text { Moneyhub Enterprise (łączy sztuczną inteligen- } \\
\text { cję, analitykę danych i psychologię, aby skłonić } \\
\text { konsumentów do wspierania pozytywnych działań } \\
\text { finansowych) } \\
\text { nViso (platforma internetowa zapewniająca ocenę } \\
\text { profili klientów generowaną przez sztuczną inteli- } \\
\text { gencję i rozpoznawanie twarzy) }\end{array}$ \\
\hline $\begin{array}{l}\text { III etap } \\
\text { grudzień } \\
2017\end{array}$ & 61 & 18 & $\begin{array}{l}\text { Curl (nowa sieć płatności konsumenckich zapro- } \\
\text { jektowana wokół otwartych interfejsów API do } \\
\text { bankowości, która działa poprzez @usernames } \\
\text { i bezpośrednie przelewy bankowe) } \\
\text { Nationwide (zautomatyzowane rozwiązanie zapew- } \\
\text { niające cyfrowe wskazówki dotyczące oszczędności } \\
\text { i porady inwestycyjne) } \\
\text { Wrisk (produkt ubezpieczeniowy zawierający treści } \\
\text { użytkowe z innowacyjną metodą oceny ryzyka) }\end{array}$ \\
\hline $\begin{array}{l}\text { IV etap } \\
\text { grudzień } \\
2018\end{array}$ & 69 & 29 & $\begin{array}{l}\text { Dashly (niezależna platforma doradztwa hipotecz- } \\
\text { nego, która śledzi i porównuje kredyt hipoteczny } \\
\text { kredytobiorcy, ostrzegając go w momencie zmiany) } \\
\text { Etherisc (usługa wykorzystująca inteligentne } \\
\text { kontrakty na blockchainie w celu zapewnienia } \\
\text { w pełni zautomatyzowanego zdecentralizowanego } \\
\text { ubezpieczenia na wypadek opóźnienia lotu) } \\
1825 \text { (zautomatyzowana propozycja doradztwa } \\
\text { dla konsumentów, którzy są bliscy przejścia na } \\
\text { emeryturę) }\end{array}$ \\
\hline
\end{tabular}

Źródło: na podstawie www.fca.org.uk. 
Jak wynika $\mathrm{z}$ danych zawartych w tabeli 1, brytyjski sandbox w ciągu półtora roku dokonał czterokrotnego naboru wniosków o udział w regulacyjnym środowisku testowym na łączną liczbę 276 innowacji. Ostatecznie, po spełnieniu kryteriów, FCA zaakceptowało do testów 89 wniosków, czyli 32\%. Omawiana piaskownica regulacyjna stała się ważnym punktem odniesienia dla innych państw, które podobnie jak Wielka Brytania stawiają sobie ambitne cele związane z szybkim rozwojem innowacyjnej i technologicznie zaawansowanej gospodarki. Dla Wielkiej Brytanii ważnym impulsem zmian było także przewidywane wyjście z Unii Europejskiej (brexit).

Powyższe cele strategiczne dały bardzo silny bodziec dla wielu państw, szczególnie z regionu Azji i Oceanii. W 2016 r. regulacyjne środowiska testowe wprowadziły: Singapur, Malezja, Hongkong, Indonezja, Tajlandia, a także Australia.

Podstawą tworzenia opisywanych rozwiązań jest z pewnością model brytyjski, jednak poszczególne państwa dostosowują organizację piaskownic regulacyjnych do swoich doświadczeń, prawodawstwa oraz specyfiki rynku. Dotychczas opublikowano kilka analiz zestawiających najważniejsze kryteria wprowadzane przez poszczególnych regulatorów/nadzorców. W tabeli 2 prezentowane są przykłady krajowych rozwiązań opracowane w 2017 r. przez Międzynarodowy Fundusz Walutowy.

Najważniejsze warunki operacyjne piaskownic regulacyjnych skierowane do potencjalnych podmiotów najczęściej z sektora fintech obejmują trzy główne fazy pilotażowe ${ }^{20}$ : fazę wejścia (warunki wyznaczane przez regulatora/nadzorcę), fazę testowania oraz fazę wyjścia, obejmującego przede wszystkim proces uczenia się i wyciągania wniosków (zarówno przez podmiot testujący, jak i podmiot publiczny) oraz zabezpieczenia w przypadku ewentualnej porażki.

Wydaje się zatem, że mamy do czynienia $\mathrm{z}$ ważnym procesem tworzenia się nowoczesnych narzędzi oceny skutków regulacji ex-ante, które obecnie nakierowane są na wspomaganie rozwoju wyodrębnionej grupy finansowych innowacji technologicznych z sektora fintech.

Do głównych korzyści tworzenia regulacyjnych środowisk testowych można zaliczyć:

- zmniejszenie bariery wejścia na rynek dla innowatorów w wysokokonkurencyjnym środowisku finansowym,

- możliwość przeprowadzenia pilotażowego badania na wybranej grupie docelowej w bezpiecznym środowisku regulacyjnym,

- obniżenie kosztów dla innowatorów (m.in. w zakresie doradztwa prawnego) oraz zwiększenie dostępu do finansowania w wyniku uzyskania od regulatora/nadzorcy specjalnego zezwolenia na prowadzenie działalności,

- skrócenie czasu uzyskania odpowiedniej licencji,

20 Na podstawie: Regulatory sandboxes. A proposal to EBA by the Banking Stakeholders Group, EBA, July 2017. 


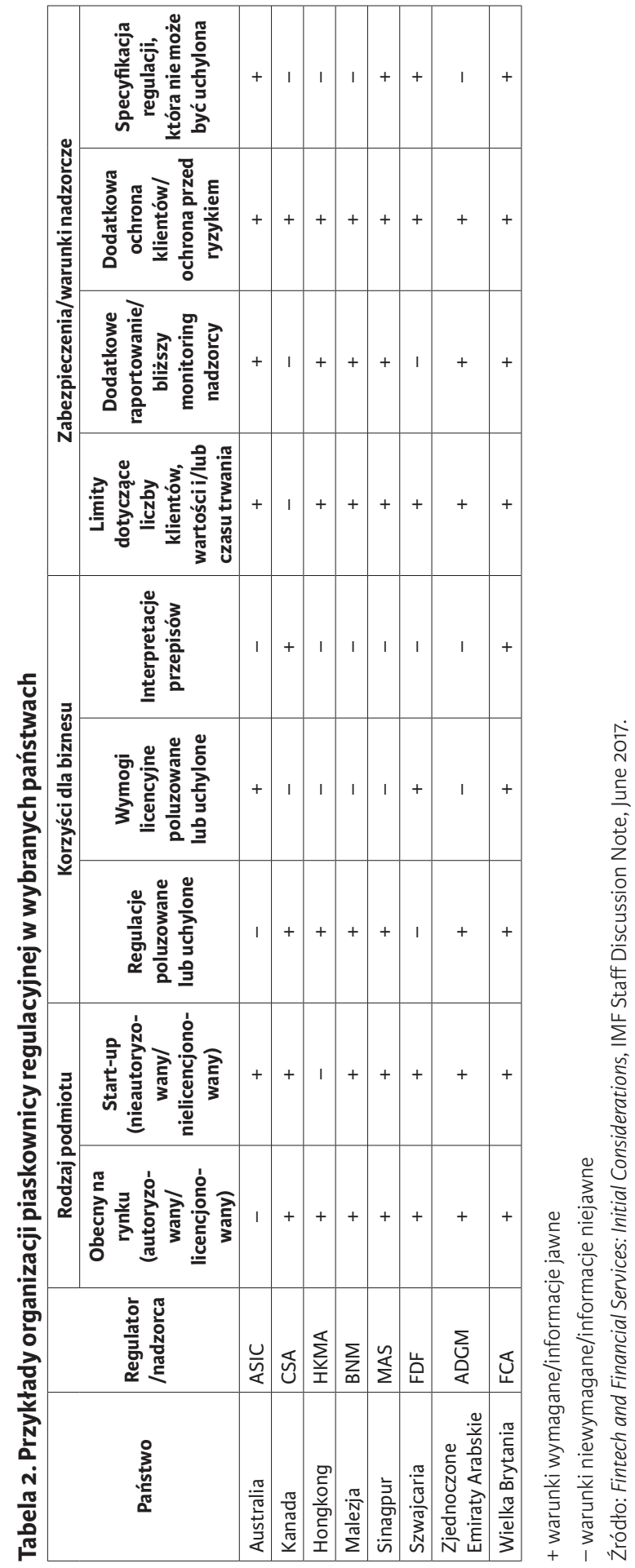


- możliwość zapewnienia określonego poziomu elastyczności przez regulatora, która może nie być dostępna w tradycyjnych modelach regulacyjnych (np. regulatorzy mogą rozluźnić określone wymogi regulacyjne dla każdego przypadku z osobna dla celów zachęcania do innowacji przy zapewnieniu odpowiednich zabezpieczeń podczas etapu testowania) ${ }^{21}$,

- polepszenie oceny skutków regulacji ex-ante przez regulatora, dzięki bezpośredniemu i indywidualnemu kontaktowi z interesariuszem,

- wprowadzenie procesu wzajemnego uczenia się podmiotu komercyjnego i publicznego,

- poprawa wizerunku nowych firm w innowacyjnym sektorze, ale także instytucji publicznych w ramach otwartych i aktywnych działań wspierających innowacyjne i ryzykowne przedsięwzięcia.

Piaskownice regulacyjne rodzą także określone obawy, spośród których można wymienić:

- osłabienie konkurencji rynkowej i możliwe sterowanie innowacyjnością przez regulatorów/nadzorców w wyniku tworzenia poglądu, że środowiska testowe są najlepszą drogą wejścia na rynek ${ }^{22}$,

- priorytetowe traktowanie podmiotów z wybranego sektora oraz wybiórcze podejście do poprawy efektywności procesu stanowienia prawa,

- „sztuczne” obniżenie ryzyka dla innowatorów, którzy w wyniku uzyskania pozytywnego przejścia przez proces testowania mogą być traktowani przez konsumentów i inwestorów jako podmioty z niskim ryzykiem działalności, co nie zawsze znajduje potwierdzenie w praktyce,

- ograniczona wydajność organizacyjna piaskownic regulacyjnych w relacji do zapotrzebowania powiązana z kosztami administracyjnymi,

- obniżenie reputacji regulatora/nadzorcy w wyniku zmaterializowania się systemowego ryzyka podmiotów związanych z sektorem fintech.

\section{Założenia polskiej piaskownicy regulacyjnej KNF}

Jak wspominano wcześniej, proces tworzenia się regulacyjnych środowisk testowych rozpoczął się w Wielkiej Brytanii, czyli w państwie członkowskim Unii Europejskiej (choć paradoksalnie przyspieszył tempo w związku z brexitem). Nie zmienia to faktu, że piaskownice regulacyjne coraz częściej będą pojawiały się w Europie, gdyż zachęty Komisji Europejskiej są jednoznaczne.

${ }^{21}$ L. Bromberg, A. Godwin, I. Ramsay, Fintech sandboxes: achieving a balance between regulation and innovation, „Journal of Banking and Finance Law and Practice” 2017, t. 28, nr 4, s. 15.

${ }^{22}$ Regulatory Sandboxes, TorontoCentre, November 2017, s. 10. 
Wydaje się jednak, że państwa członkowskie UE postawione zostały przed dylematem wyboru modelu anglosaskiego (z piaskownicami regulacyjnymi) czy też modelu niemieckiego (bez piaskownic). $\mathrm{W}$ tym ostatnim regulatorzy i nadzorcy niemieccy stoją na stanowisku, że każda firma musi spełniać te same wymogi prawne. Oznacza to, że aby uzyskać zezwolenie, firmy z sektora fintech muszą pokonać wysokie przeszkody, czyli (w zależności od modelu biznesowego) muszą zgromadzić znaczną ilość kapitału założycielskiego, ustanowić system zarządzania ryzykiem, wykazać się profesjonalizmem i wiarygodnością dyrektorów zarządzających oraz zainstalować system bezpieczeństwa informatycznego ${ }^{23}$.

Widoczna presja na rozwój innowacyjności powoduje, że kolejne państwa europejskie skłaniają się jednak w kierunku modelu anglosaskiego. Wśród nich są już Holandia, Dania, także od niedawna Litwa ${ }^{24}$ i Węgry ${ }^{25}$, a kolejne państwa wpisują sandboxy w swoje strategie digitalizacji gospodarki oraz proponują zmiany prawne w tym zakresie (np. Hiszpania ${ }^{26}$ ). Propozycje te najczęściej są również wynikiem przeprowadzanych konsultacji $z$ interesariuszami ${ }^{27}$.

W związku z powyższym można uznać, że Polska wpisuje się w model anglosaski, odpowiadając na zgłaszane zapotrzebowanie z nowo tworzącego się segmentu fintech ${ }^{28}$ oraz przyjmując rolę jednego z pionierów i innowatorów w podejściu regulacyjnym.

W ogłoszonej w 2017 r. „Krajowej strategii fintech”29 jako jedno z założeń dotyczące optymalizacji instytucji regulacyjno-nadzorczych przyjęto powołanie przez Urząd Komisji Nadzoru Finansowego (UKNF) piaskownicy regulacyjnej KNF. Sandbox ma stanowić drugie, po Innovation Hub, narzędzie zastosowane przez Urząd.

Zgodnie z regulaminem programu przez piaskownicę regulacyjną należy rozumieć działające $\mathrm{w}$ modelu zdecentralizowanym środowisko informatyczne, służące do przeprowadzania testów innowacyjnych rozwiązań finansowych, wdrażanych przy wykorzystaniu nowoczesnych technologii (fintech), udostępniane podmiotom testującym przez operatora piaskownicy, nad którym UKNF sprawuje patronat. Tym samym podmiotem testującym w rozumieniu regulami-

${ }^{23}$ No „Sandbox” in Germany, „Financial Services Observer” April 2017.

${ }^{24} \mathrm{Https} / / / \mathrm{www} . l \mathrm{lb} . \mathrm{lt} / \mathrm{en} / \mathrm{news} / \mathrm{lithuania-s-financial-regulator-launches-its-regulatory-}$ -sandbox.

${ }^{25} \mathrm{Https} / /$ paymentscompliance.com/premium-content/research_report/hungary-central-bank-launches-regulatory-sandbox-commence-operations.

${ }^{26} \mathrm{Http}: / /$ www.osborneclarke.com/insights/regulatory-sandbox-in-spain-the-draft-bill-for-the-law-of-digital-transformation-of-the-financial-system/.

27 Na przykład https://www.mnb.hu/letoltes/consultation-document.pdf.

${ }_{28}$ Zob. wyniki prac Zespołu roboczego ds. rozwoju innowacji finansowych (FinTech), KNF, https://www.knf.gov.pl/knf/pl/komponenty/img/Raport_KNF_11_2017_60290.pdf.

29 FinTech Hub Polska - jak skutecznie zbudować centrum finansowe nowej generacji w Polsce, raport FinTech Poland, 2017, s. 67. 
nu jest podmiot $\mathrm{z}$ siedzibą na terytorium Rzeczypospolitej Polskiej, prowadzący działalność nadzorowaną lub zamierzający ją podjąć, który posiada innowacyjne rozwiązanie finansowe wdrażane przy wykorzystaniu nowoczesnych technologii, testowane w piaskownicy. Operatorem piaskownicy może zostać podmiot również z siedzibą na terytorium Rzeczpospolitej Polskiej, mający możliwość udostępnienia działającego i spełniającego wymogi UKNF środowiska testowego, który udostępnia podmiotom testującym środowisko niezbędne do przeprowadzenia testów usługi lub modelu biznesowego, a także zapewnia konieczny katalog szkoleń związanych z prowadzoną przez podmiot testujący działalnościąa ${ }^{30}$.

Do kryteriów wejścia do piaskownicy regulacyjnej KNF należą ${ }^{31}$ :

- zakres rozwiązania, co oznacza, że klasyfikacji będą podlegać podmioty i ich produkty lub usługi, które noszą cechy działalności nadzorowanej przez KNF, a także cechy wsparcia lub rozwoju przedmiotowej działalności,

- innowacyjny charakter rozwiązania, oznaczający w zasadzie dwa warunki, czyli określoną unikalność rynkową rozwiązania oraz wkład do rozwoju sektora innowacji finansowych w Polsce,

- realna potrzeba udziału w piaskownicy, czyli uzasadnienie zawierające problemy kosztowe związane z tradycyjnym wdrożeniem na rynku, jak również występująca luka prawna ograniczająca to wdrożenie,

- gotowość do przeprowadzenia testów, co oznacza określony poziom dojrzałości proponowanego rozwiązania.

Po zakwalifikowaniu do piaskownicy podmiot testujący będzie mógł przeprowadzić testy w okresie od 3 do 9 miesięcy (w uzasadnionych przypadkach okres ten można będzie wydłużyć do roku). Środowisko testowe będzie udostępniane przez wybranego przez UKNF operatora piaskownicy w formie wirtualnej (zinformatyzowanej) z możliwością wykorzystania zanonimizowanych danych lub rzeczywistej, czyli na udostępnionej przez operatora bazie klientów, którzy wyrażą chęć uczestnictwa $\mathrm{w}$ teście. $\mathrm{W}$ trakcie testowania podmioty testujące nie będą mogły przyjmować płatności od klientów, ale będą mogły im zapłacić za ocenę i wyrażenie opinii. UKNF przeprowadził już nabór na operatorów piaskownicy, podczas którego wyłonionych zostało osiem podmiotów, tj. PKO Bank Polski SA, Huge Thing Sp. z o.o., D-RAFT SA (The Heart), Alior Bank SA, Fundacja Rozwoju Przedsiębiorczości BusinessCaddy, Bank Pekao SA, Bank Handlowy w Warszawie SA, Bank BGŻ BNP Paribas SA. Operatorzy piaskownicy odpowiedzialni są za przygotowanie środowiska testowego oraz opracowanie

${ }^{30}$ Regulamin programu piaskownica regulacyjna w Urzędzie Komisji Nadzoru Finansowego, KNF.

31 Urząd KNF uruchamia piaskownicę regulacyjną KNF, KNF, 25 październik 2018 r., www.knf.gov.pl. 
niezbędnych procedur wewnętrznych związanych z prowadzeniem piaskowni$\mathrm{cy}^{32}$. Rola UKNF sprowadzać ma się zatem do ${ }^{33}$ :

- akceptacji wniosku o uczestnictwo w piaskownicy regulacyjnej na podstawie oceny wydanej przez operatora piaskownicy,

- monitorowania testów oraz konsultacji prawnoregulacyjnych w zakresie procesu uzyskania licencji,

- oceny wyników przeprowadzonych testów,

- wydania licencji.

Polska piaskownica regulacyjna miała rozpocząć działalność w I kwartale 2019 r.

\section{European regulatory sandbox - czy jest możliwy?}

Z przedstawionej wyżej analizy wynika, że inicjatywa tworzenia regulacyjnych środowisk testowych pojawiła się na poziomie krajowym. Z punktu widzenia Unii Europejskiej jest to zatem rozwiązanie oddolne, wspierające strategiczne krajowe cele rozwojowe i odwołujące się do obowiązującej w Unii zasady subsydiarności (pomocniczości), która określa, że działania na poziomie ponadnarodowym powinny być podjęte tylko w wówczas, gdy cele danego przedsięwzięcia na poziomie krajowym mogą nie odnosić zamierzonego skutku. Na odpowiedź na pytanie o ocenę tej skuteczności jest na razie za wcześnie.

Warto jednak podkreślić, że pojawiają się coraz to nowe argumenty za ewentualnym ustanowieniem europejskiej piaskownicy regulacyjnej z różnymi wariantami jej udziału w przedstawionych wyżej procesach. Wśród przesłanek tego rozwiązania można wyróżnić następujące:

- na poziomie ponadnarodowym cele prorozwojowe są zbieżne z celami krajowymi. Strategie zaakceptowane na poziomie UE, w tym „Strategia jednolitego rynku cyfrowego dla Europy” ${ }^{34}$ czy też „Strategia UE w zakresie cyberbezpieczeństwa" ${ }^{35}$, jak również przyjęte prawodawstwo, w tym

${ }^{32}$ Na podstawie informacji przygotowanej przez Departament Innowacji Finansowych FinTech w Urzędzie Komisji Nadzoru Finansowego na potrzeby prac Biura Analiz Sejmowych, 12 grudnia 2018 r. W tym: zasady naboru i kwalifikacji podmiotów testujących do piaskownicy regulacyjnej KNF, zasady przeprowadzania testów w piaskownicy regulacyjnej KNF (m.in. zasady ustalania planu testów, w tym parametrów i scenariuszy testów, zasady postępowania $\mathrm{w}$ związku z pozytywnym i negatywnym zakończeniem testów - strategia wyjścia), zasady sprawowania nadzoru nad podmiotem testującym (w tym zasady oceny i kontroli podmiotu testującego), zasady raportowania do UKNF o wynikach testów i postępach podmiotu testującego.

${ }^{33}$ Https://www.knf.gov.pl/dla_rynku/fin_tech/Piaskownica_regulacyjna_KNF.

${ }^{34} \operatorname{COM}(2015) 192$ final.

35 JOIN(2017) 450 final. 
rozporządzenie eIDAS ${ }^{36}$, czy wiele regulacji dotyczących usług finansowych, są wyraźnym dowodem na konieczność wdrożenia jednolitego podejścia do rozwoju segmentu rynku fintech,

- zgodnie w przyjętym „Planem działania w zakresie technologii finansowej" Komisja Europejska zaproponowała kilka nowych inicjatyw na poziomie europejskim w zakresie wsparcia rozwoju bardziej konkurencyjnego i innowacyjnego europejskiego sektora finansowego, będących $\mathrm{w}$ fazie konsultacji lub wdrożenia (m.in. Unijne Obserwatorium i Forum ds. Łańcucha Bloków, Unijne Laboratorium Fintech, Europejska Brama Przejrzystości Finansowej),

- zarówno Komisja Europejska, jak i Parlament Europejski wdrożyły już wiele nowych rozwiązań w ramach reformy lepszego tworzenia prawa (better regulations), w tym szczególnie oceny skutków regulacji, m.in. niezależną Radę ds. Kontroli Regulacji (Komisja Europejska), specjalny dyrektoriat ds. oceny skutków regulacji oraz europejskiej wartości dodanej (Parlament), program REFIT, skupiający ekspertów ze wszystkich 28 państw członkowskich Unii ${ }^{37}$, co wskazuje na szeroką aktywność regulatorów w tym zakresie i otwartość na nowe rozwiązania,

- dodać też należy, że brytyjski Urząd Nadzoru Finansowego, uznając transgraniczny charakter wielu testowanych innowacji, już w połowie 2018 r. powołał Global Financial Innovation Network (GFIN) ${ }^{38}$ i rozpoczął konsultacje na temat utworzenia globalnej piaskownicy regulacyjnej (global sandbox), która miałaby działać na szerokim poziomie międzynarodowym w konstrukcji sieciowej,

- pojawiają się już propozycje utworzenia transgranicznych środowisk testowych (cross-border sandboxes) ${ }^{39}$, jak i europejskiej piaskownicy regulacyjnej (European sandbox $)^{40}$, a także analizy naukowe w tym zakresie ${ }^{41}$.

Wydaje się, że najbardziej realne możliwości uczestnictwa europejskich regulatorów/nadzorców w procesie tworzenia regulacyjnych środowisk testowych mogą dotyczyć czterech rozwiązań:

${ }_{36}$ Rozporządzenie Parlamentu Europejskiego i Rady (UE) nr 910/2014 z 23 lipca 2014 r.

37 Więcej na ten temat zob. K. Marchewka-Bartkowiak, Nowe rozwiązania regulacyjne - RIA, sandbox, compliance, RegTech - w świetle procesu „inflacji” prawa finansowego, „Studia BAS” 2018, nr 1(53) [Nowa architektura europejskiego systemu finansowego, red. K. Marchewka-Bartkowiak].

${ }_{38}$ Https://www.fca.org.uk/publications/consultation-papers/global-financial-innovation-network.

39 Regulatory sandboxes, EBA, op. cit., s. 13.

${ }^{40}$ FinTech: a more competitive and innovative European financial sector, Consultation document, European Commission, 2017, s. 16-17.

${ }^{41}$ Zob. m.in. W.-G. Ringe, C. Ruof, A Regulatory Sandbox for Robo Advice, EBI, 2 maja 2018 r. 
- ograniczenie działań tylko do wydawania standardów i wytycznych do krajowych piaskownic regulacyjnych w UE,

- stworzenie forum (platformy) wymiany doświadczeń z elementem raportowania na rzecz europejskiego regulatora/nadzorcy,

- powołanie odrębnej europejskiej piaskownicy regulacyjnej dysponującej określonymi wariantami udziału regulatorów/nadzorców z państw członkowskich z ewentualną możliwością delegowania procesu testowania do wybranej krajowej piaskownicy regulacyjnej,

- powołanie europejskiej piaskownicy regulacyjnej przeprowadzającej testy tylko w ramach zadeklarowanej działalności podmiotu z sektora fintech lub skutków wdrożenia innowacji o charakterze transgranicznym (ponadnarodowym).

Powyższe propozycje prezentowane są w hierarchii od „podejścia miękkiego", w którym rolą instytucji europejskich jest wytyczanie wspólnych kierunków, po „podejście twarde”, traktujące europejski sandbox jako odrębne organizacyjnie przedsięwzięcie.

Ze względu jednak na fakt, że zakres dotychczasowych doświadczeń z funkcjonowania regulacyjnych piaskownic w Europie jest na razie niewielki, trudno wskazać obecnie najlepsze rozwiązanie.

\section{Podsumowanie}

Regulacyjne środowiska testowe uznać należy za innowacyjne narzędzia wsparcia przez instytucje publiczne rozwoju nowych, szybko rozwijających się, ale jednocześnie ryzykownych sektorów. Pomysł, który narodził się w Wielkiej Brytanii i został dość szybko skopiowany w innych państwach, urasta obecnie do rangi jednego z kluczowych obszarów zmniejszania bariery rozwoju rynku fintech, jakim są regulacje prawne.

Nie rozwiązuje to jednak podstawowego problemu, jakim jest nienadążanie regulacji za szybko ewoluującymi zmianami technologicznymi, a tym samym rynkowymi, gospodarczymi i społecznymi. Ponadto wraz z dalszym rozwojem konieczne stanie się także opracowanie metody oceny ex-post, która równie sprawnie wskaże błędy i złe doświadczenia wynikające z przedstawionych $\mathrm{w}$ artykule procesów.

\section{Bibliografia}

Bromberg L., Godwin A., Ramsay I., Fintech sandboxes: achieving a balance between regulation and innovation, „Journal of Banking and Finance Law and Practice” 2017, t. 28 , nr 4 . 
Discussion Paper on the EBA's approach to financial technology (fintech), EBA, August 2017.

Fintech and Financial Services: Initial Considerations, IMF Staff Discussion Note, June 2017.

Fintech Hub Polska - jak skutecznie zbudować centrum finansowe nowej generacji w Polsce, raport FinTech Poland, 2017.

FinTech: a more competitive and innovative European financial sector, Consultation document, European Commission, 2017.

No „Sandbox” in Germany, „Financial Services Observer” April 2017.

Marchewka-Bartkowiak K., Nowe rozwiazania regulacyjne - RIA, sandbox, compliance, RegTech - w świetle procesu ,inflacji” prawa finansowego, „Studia BAS” 2018, nr 1(53) [Nowa architektura europejskiego systemu finansowego, red. K. Marchewka-Bartkowiak].

Marchewka-Bartkowiak K., Wyzwania regulacyjne związane $z$ innowacjami technologicznymi i produktowymi [w:] Banki w nowym otoczeniu społecznym, gospodarczym i technologicznym, red. E. Miklaszewska, Poltext, Warszawa 2018.

Regulatory sandboxes. A proposal to EBA by the Banking Stakeholders group, EBA, July 2017.

Regulatory sandbox, FCA, November 2015.

Regulatory Sandboxes, TorontoCentre, November 2017.

Ringe W.-G., Ruof C., A Regulatory Sandbox for Robo Advice, EBI, 2 maja 2018 r.

Szpringer W., Nowe technologie a sektor finansowy. Fintech jako szansa i zagrożenie, Poltext, Warszawa 2018.

\section{Akty prawne}

Regulamin programu piaskownica regulacyjna w Urzędzie Komisji Nadzoru Finansowego, KNF.

Rozporządzenie Parlamentu Europejskiego i Rady (UE) nr 910/2014 z 23 lipca 2014 r.

\section{Strony internetowe}

Www.fca.org.uk/firms/regulatory-sandbox.

Www.dnb.nl/en/supervision/innovationhub/maatwerk-voor-innovatie-regulatorysandbox/index.jsp.

Www.finanstilsynet.dk/en/Tilsyn/Information-om-udvalgtetilsynsomraader/ Fintech/ FT-Lab.

Www.finma.ch/en/news/2016/03/20160317-mm-fintech.

Https://asic.gov.au/for-business/your-business/innovation-hub/regulatory-sandbox.

Www.securities-administrators.ca/industry_resources.aspx?id=1588.

Www.hkma.gov.hk/eng/key-functions/international-financial-centre/fintech-supervisorysandbox.shtml.

Www.mas.gov.sg/Singapore-Financial-Centre/Smart-Financial-Centre/fintech-Regulatory-Sandbox.aspx. 
Www.bi.go.id/en/ruang-media/siaran-pers/Pages/sp_187316.aspx.

Www.bnm.gov.my/index.php?ch=en_announcement\&pg=en_announcement $\& a c=467$. Www.fsc.gov.tw.

Www.fintech.adgm.com/regulatory-laboratory.

Www.azag.gov/press-release/arizona-becomesfirst-state-us-offer-fintech-regulatory-sandbox.

Www.lb.lt/en/news/lithuania-s-financial-regulator-launches-its-regulatory-sandbox.

Www.paymentscompliance.com/premium-content/research_report/hungary-central-bank-launches-regulatory-sandbox-commence-operations.

Www.osborneclarke.com/insights/regulatory-sandbox-in-spain-the-draft-bill-for-the-law-of-digital-transformation-of-the-financial-system/.

Www.mnb.hu/letoltes/consultation-document.pdf.

Www.knf.gov.pl/dla_rynku/fin_tech/Piaskownica_regulacyjna_KNF. 